\title{
Parathyroid hormone: an early predictor of symptomatic hypocalcemia after total thyroidectomy
}

\author{
Hormônio da paratireoide: um preditor precoce da \\ hipocalcemia sintomática após a tireoidectomia total
}

Felipe Augusto Brasileiro Vanderlei', Jose Gilberto Henriques Vieira², Flavio Carneiro Hojaij', Onivaldo Cervantes' ${ }^{1}$ Ilda Sizue Kunii², Monique Nakayama Ohe'2, Rodrigo Oliveira Santos' ${ }^{1}$, Marcio Abrahão'

1 Head and Neck Surgery, Universidade Federal de São Paulo (Unifesp), São Paulo, SP, Brazil 2 Endocrinology, Unifesp, São Paulo, SP, Brazil
Correspondence to:

Felipe Augusto Brasileiro Vanderlei Rua Mato Grosso, 306, conj. 1804 01239-040 - São Paulo, SP, Brazil fabvanderlei@terra.com.br

Received on 5/Sept/2011 Accepted on 23/Mar/2012

\section{ABSTRACT}

Objective: The purpose of this study was to evaluate if the measurement of peri-operative parathyroid hormone (PTH) is able to identify patients with increased risk of developing symptoms of hypocalcemia. Subjects and methods: Forty patients who underwent total thyroidectomy were studied prospectively. lonized serum calcium and PTH were measured after induction of anesthesia, one hour (PTH1) and one day after surgery (PTH24). Patients were evaluated for symptoms of hypocalcemia and treated with calcium and vitamin D supplementation as necessary. Results: Symptomatic hypocalcemia developed in 16 patients. Symptomatic patients had significant lower PTH1 and greater drops in PTH levels. The selection of $12.1 \mathrm{ng} / \mathrm{L}$ as PTH1 level cutoff level divided patients with and without symptoms with $93.7 \%$ sensitivity and $91.6 \%$ specificity. The selection of $73.5 \%$ as the cutoff value for PTH decrease resulted in $91.6 \%$ sensitivity and $87.5 \%$ specificity. Conclusion: PTH1 levels and the drop in PTH levels are reliable predictors of developing symptomatic hypocalcemia after total thyroidectomy. Arq Bras Endocrinol Metab. 2012;56(3):168-72

\section{Keywords}

Thyroid gland; PTH; hypocalcemia; thyroidectomy; parathyroid gland

\section{RESUMO}

Objetivo: O objetivo deste estudo é avaliar se a medida perioperatória do hormônio da paratireoide (PTH) pode identificar os pacientes com maior risco de desenvolver sintomas de hipocalcemia. Sujeitos e métodos: Foram estudados quarenta pacientes submetidos à tireodiectomia total. A medida do cálcio sérico e do PTH foi feita após a indução anestésica, uma hora (PTH1) e um dia após a cirurgia. Os pacientes foram avaliados quanto à presença de sintomas de hipocalcemia e tratados com suplementação de cálcio e vitamina D quando necessário. Resultados: Dezesseis pacientes apresentaram sintomas de hipocalcemia. Os pacientes sintomáticos apresentaram PTH1 significantemente menor e queda no PTH significativamente maior. Usando o valor de 12,1 ng/L como corte, conseguimos distinguir pacientes com e sem sintomas de hipocalcemia com sensibilidade de $93,7 \%$ e especificidade de $91,6 \%$. Utilizando como corte a queda de $73,5 \%$ no valor do PTH, temos sensibilidade de $91,6 \%$ e especificidade de $87,5 \%$. Conclusão: O PTH1 e a queda no PTH são bons preditores de hipocalcemia no pós-operatório de tireoidectomia total Arq Bras Endocrinol Metab. 2012;56(3):168-72

\section{Descritores}

Glândula tireoide; PTH; hipocalcemia; tiroidectomia; glândula paratireoide 


\section{INTRODUCTION}

$\mathrm{T}$ hyroidectomy has been performed since $500 \mathrm{AD}$, and initially presented very high morbidity and mortality that persisted even to the time of Billroth, who in 1883 reported a $40 \%$ mortality rate in 20 thyroidectomies. This high mortality possibly reflected a lack of knowledge concerning the parathyroid glands and their influence on calcium metabolism (1). By 1912, Theodore Kocher recognized the need to preserve parathyroid glands, and had successfully performed more than 5000 , mostly subtotal thyroidectomies (1-3).

Hypocalcemia, usually transient, is the most common complication following total thyroidectomy, and occurs in $10 \%$ to $50 \%$ of cases. It is the result of parathyroid gland injury and can cause great discomfort to the patient $(1,4-8)$.

Symptoms of serum hypocalcemia may not be manifest for up to four days after surgery and can significantly lengthen hospital stay (4,9-11). Finding a simple and reliable method to predict which patients may show hypocalcemia could decrease patient discomfort, hospital stay and treatment costs associated with total thyroidectomy.

The purpose of this study is to evaluate if peri-operative measurement of parathyroid hormone $(\mathrm{PTH})$ during total thyroidectomy may identify those patients with the greatest risk of developing symptoms of hypocalcemia.

\section{SUBJECTS AND METHODS}

We developed a prospective study in the São Paulo Hospital of the Universidade Federal de São Paulo (Brazil) from January to August, 2006. Informed consent was obtained from all subjects, and the study was approved by the Research Ethics Committee of the Universidade Federal de São Paulo. The first author was present at all surgical procedures.

Forty-four consecutive patients who underwent total thyroidectomy without simultaneous neck dissection were included. Four patients were eliminated: two had parathyroid adenomas identified during surgery, one because of problems in blood sample identification, and one because the patient was unable to adequately express herself. Therefore, information about forty patients was analyzed ( 37 females and 3 males).

Ionized calcium and PTH levels were measured before the operation (induction of anesthesia - $\mathrm{Ca} 0$ / PTH0), one hour after the surgery (in the recovery room - $\mathrm{Cal} / \mathrm{PTHl})$ and on the day following surgery (Ca24/PTH24). Vitamin D levels were also determined. Ionized calcium measurements were carried out in an AVL 9180 - Eletrolyte Analyzer, and PTH measurements in Roche Elecsys 1010, which provides results in approximately 10 minutes. The normal values for ionized calcium are 1.24-1.41 mmol/L and PTH 15-65 ng/L. Vitamin D levels were determined by radioimmunoassay with Dia Sorin kit, and the measurement was carried out using Wallac 1277 Gammamaster gamma counter. The normal levels for vitamin $\mathrm{D}$ are 30-60 ng/mL.

Patients were monitored for postoperative symptoms of hypocalcemia: development of perioral or fingertip paresthesias or numbness, muscle cramping, tetany, or positive Chvostek's or Trousseau's sign. Patients were divided in two groups - those with and those without symptoms, and comparisons were made between the two groups.

Symptomatic patients were treated with calcium and vitamin D supplementation and discharged when signs and symptoms were controlled. After discharge, patients were instructed to call the researchers if they developed any symptoms of hypocalcemia. All patients were evaluated in the $7^{\text {th }}$ and $13^{\text {th }}$ postoperative day, and then, every three months.

Statistical analyses were made with SPSS 13.0 for Windows, LEAD Technologies, Inc. The groups were compared using a Person's $\mathrm{X}^{2}$ and Student's $t$ test. Differences were considered significant when $\mathrm{p}<0.05$.

\section{RESULTS}

Sixteen of forty $(40 \%)$ total thyroidectomy patients developed symptoms of hypocalcemia. Thirty four patients were discharged on the first postoperative day, five on the second, and the patient who experienced the greatest drop in PTH levels (92\%) and the lowest PTH concentration $(5 \mathrm{ng} / \mathrm{L})$ one hour after the surgery was hospitalized for five days.

All patients were discharged without symptoms or signs of hypocalcemia. Eight patients became symptomatic on the first postoperative day, six on the second, and two only on the third postoperative day. Patients were followed up for at least 10 months (10-18 months), and only one patient $(2.5 \%)$ needed calcium supplementation six months after surgery. No patient needed to be readmitted to the hospital after discharge, and there were no surgical complications. 
Mean age of symptomatic patients was $53.6 \pm 16.5$ years, and for patients without symptoms $50.1 \pm 14.7$ years $(\mathrm{p}=0.48)$. Four parathyroid glands were identified in 19 patients, three in 16 patients, two parathyroid glands in three pacients, and only one parathyroid was identified in two patients. The number of parathyroid glands identified was not statistically different between symptomatic and asymptomatic patients $(\mathrm{p}=0.46)$. Ten patients needed parathyroid transplantation (one parathyroid in nine patients, and two parathyroids in one patient). Among those patients who needed parathyroid transplantation, six $(60 \%)$ became symptomatic, and in the group that did not need parathyroid transplantation, 10 patients $(33 \%)$ became symptomatic. This difference, however, was not significant $(\mathrm{p}=$ $0.136)$. Vitamin D levels were also similar in the symptomatic and asymptomatic groups $(21.6 \pm 8.2 \mathrm{ng} / \mathrm{mL}$ and $23.9 \pm 7.4 \mathrm{ng} / \mathrm{mL}, \mathrm{p}=0.88$ ). Six patients showed hyperthyroidism in the preoperative period, and two $(33 \%)$ of them developed symptoms of hypocalcemia.

In the group that did not develop symptoms, mean values were: $56.6 \pm 24.4 \mathrm{ng} / \mathrm{L}$ for PTH0, $27.7 \pm 14.5$ $\mathrm{ng} / \mathrm{L}$ for PTHl, $26.8 \pm 11.4 \mathrm{ng} / \mathrm{L}$ for PTH24, $1.23 \pm$ $0.7 \mathrm{mmol} / \mathrm{L}$ for $\mathrm{Ca} 0,1.21 \pm 0.7 \mathrm{mmol} / \mathrm{L}$ for $\mathrm{Cal}$, and $1.15 \pm 0.6 \mathrm{mmol} / \mathrm{L}$ for $\mathrm{Ca} 24$. In those who developed symptoms, mean values were: $56.1 \pm 18.5 \mathrm{ng} / \mathrm{L}$ for PTH0, $9.5 \pm 6.5 \mathrm{ng} / \mathrm{L}$ for PTHl, $8.0 \pm 3.4 \mathrm{ng} / \mathrm{L}$ for PTH24, $1.21 \pm 0.5 \mathrm{mmol} / \mathrm{L}$ for $\mathrm{Ca} 0,1.17 \pm 0.5$ $\mathrm{mmol} / \mathrm{L}$ for $\mathrm{Cal}$ and $1.05 \pm 0.5 \mathrm{mmol} / \mathrm{L}$ for $\mathrm{Ca} 24$. $\mathrm{Ca} 0, \mathrm{PTH} 0$ and $\mathrm{Cal}$ were similar between symptomatic and asymptomatic groups $(\mathrm{p}=0.47, \mathrm{p}=0.94$, and $\mathrm{p}$ $=0.07$ respectively). Patients in the symptomatic group had PTHI significantly lower than patients in the asymptomatic group $(\mathrm{p}<0.001)$ (Figure 1). PTH24 and $\mathrm{Ca} 24$ were also statistically different between symptomatic and asymptomatic patients $(\mathrm{p}<0.001)$. Thirty eight patients (95\%) had ionized calcium levels below normal range in the first postoperative day, and the other two had ionized calcium levels in the lower limit of the reference range $(1.24 \mathrm{mmol} / \mathrm{L})$.

PTH drop (difference between PTHI and PTH0) was greater in the symptomatic group $(82.2 \pm 8.8 \% v v$. $47.4 \pm 6.4 \%, \mathrm{p}<0.001)$ compared to the group of $\mathrm{pa}-$ tients without symptoms (Figure 2).

PTHl value below $12.1 \mathrm{ng} / \mathrm{L}$ predicted which patient had a greater chance of developing symptoms of hypocalcemia with $93.7 \%$ sensitivity and $91.6 \%$ specificity. PTH drop of $73.5 \%$ also effectively predicted symptoms of hypocalcemia among patients who underwent total thyroidectomy with $91.6 \%$ sensitivity and $87.5 \%$ specificity. The Roc curves show that both PTHI value and PTH drop are reliable predictors of symptoms of hypocalcemia. Using $12.1 \mathrm{ng} / \mathrm{L}$ as PTHl cutoff value, the area under the curve is 0.927 (Figure 3), and using $73.5 \%$ as PTH drop cutoff value, the area under the curve is 0.896 (Figure 4).

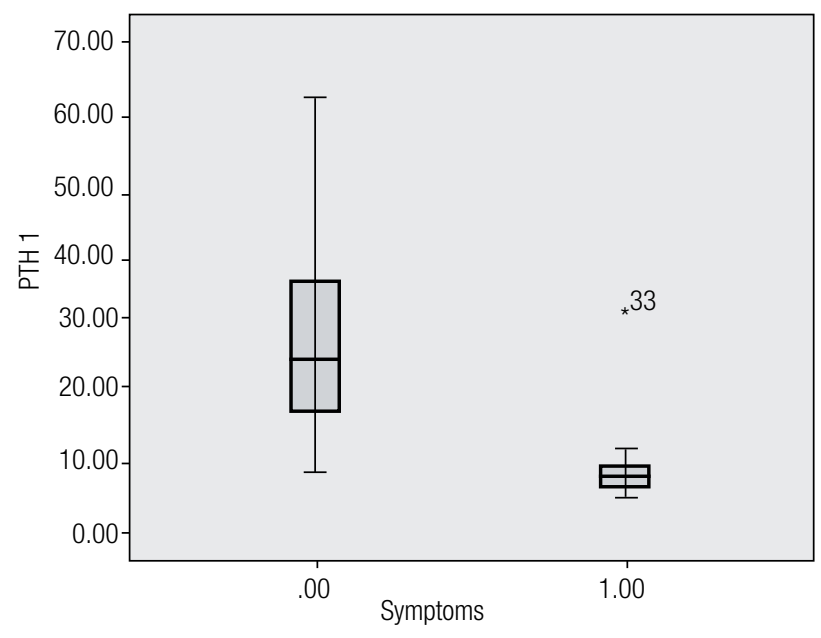

0.0: patients without symptoms; 1.00 : patients with symptoms.

Figure 1. PTH 1 hour after the surgery.

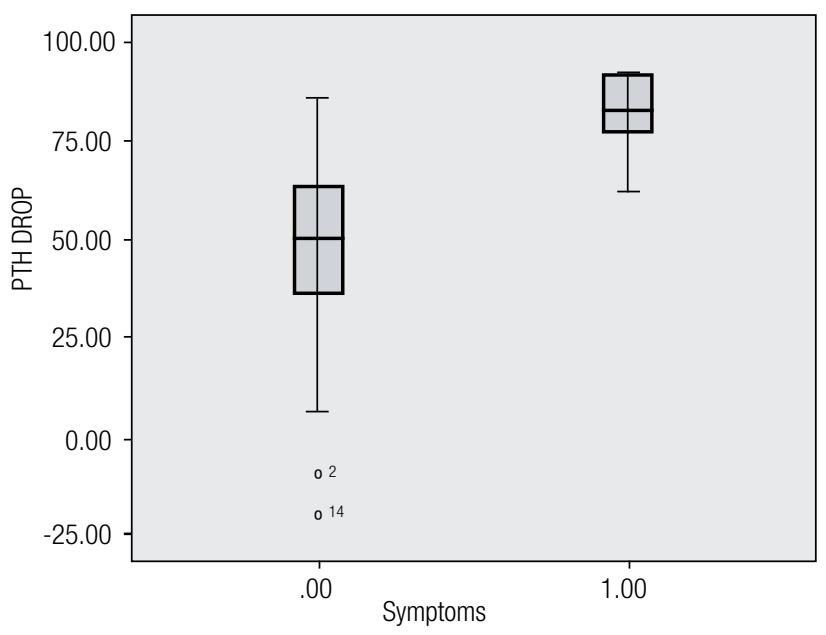

0.00: patients without symptoms; 1.00 : patients with symptoms.

Figure 2. PTH drop (difference between PTH at induction and PTH one hour after surgery). 


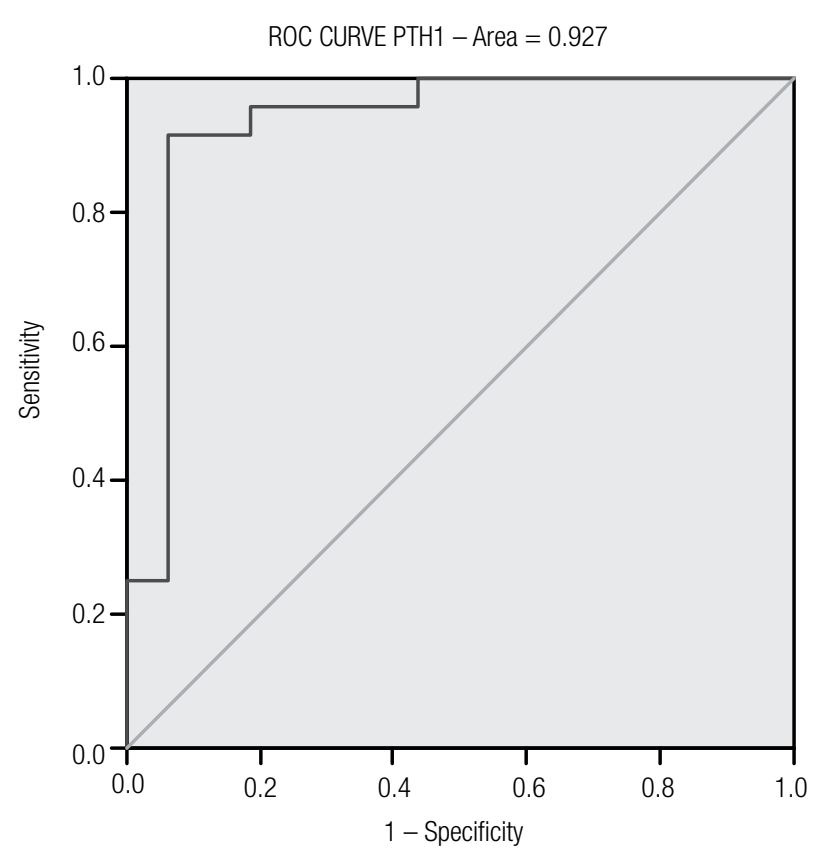

Figure 3. Roc curve with TH1 cutoff value of $12.1 \mathrm{ng} / \mathrm{L}$.

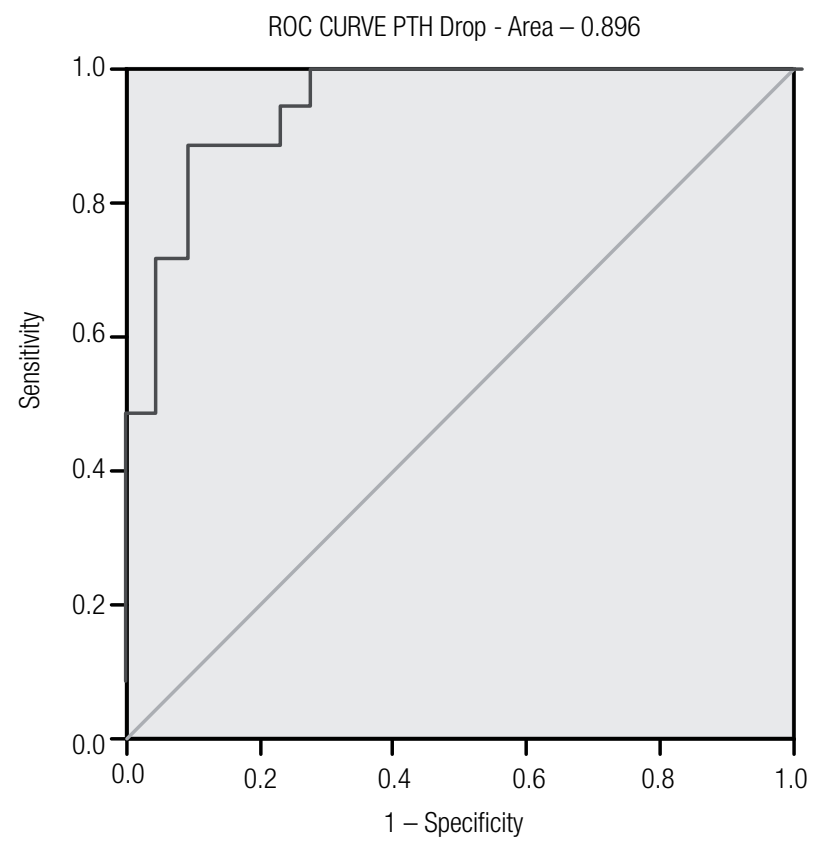

Figure 4. Roc curve with cutoff value of $73.5 \%$ for PTH drop.

\section{DISCUSSION}

Hypocalcemia is the most frequent complication of total thyroidectomy. Some physicians prescribe supplementation of calcium and vitamin D to all total thyroidectomy patients, while others obtain serial calcium determinations to try to predict which patients will develop hypocalcemia. Neither strategy seems to be cost-effective, the former because all patients are exposed to side effects of calcium but less than half actually need the supplementation, and the latter because it can delay discharge and subject the patient to the discomfort of multiple venipuntures. Some protocols based on calcium slope are useful (12-14), but still require serial measurements, postpone treatment and may prolong hospital stay. It is still difficult to predict whether a patient has a greater risk of developing hypocalcemia based only on calcium levels or surgical events $(15,16)$.

The success of rapid PTH determinations in parathyroid surgery led some investigators to evaluate its usefulness to predict hypocalcemia following thyroid surgery. Lam and Kerr found that all patients with PTH value less than $8 \mathrm{pg} / \mathrm{mL}$ measured one hour after the surgery became hypocalcemic, and all patients with PTH level greater than $9 \mathrm{pg} / \mathrm{mL}$ did not (17). Higgins and cols. demonstrated that $64 \%$ of those patients who subsequently required calcium supplementation had a decrease in PTH levels greater than 75\% from baseline 20 minutes after surgery, and $74 \%$ of those who did not need calcium supplementation demonstrated a decrease of less than $75 \%$ from baseline (18). For Lombardi and cols., PTH less than $10 \mathrm{pg} / \mathrm{mL}$ measured four or six hours after surgery predicted hypocalcemia with an overall accuracy of 98\% (19). Pattou and cols. reported that a postoperative PTH level of $12 \mathrm{pg} / \mathrm{mL}$ or less was a good predictor of hypocalcemia, but did not state how long after surgery PTH values were obtained (20). A group of Australian surgeons found that normal postoperative PTH levels accurately predicted normocalcemia after total thyroidectomy, and the optimal time to make the measurement was four hours after the surgery (21).

Almost all studies define hypocalcemia as either low serum calcium or development of symptoms of hypocalcemia $(9,11,15-19,21-26)$. We used only the symptoms of hypocalcemia because we believe that mixing two parameters (biochemical hypocalcemia and symptomatic hypocalcemia) can introduce a bias. Postoperative serum calcium level can take up to four days to reach its lowest value (20) and, like Richards and cols., we also found that almost all patients have calcium levels below reference range after total thyroidectomy (27). Furthermore, the speed of decrease in calcium levels appears to be more important that the absolute value itself $(4,20)$. 
Similar to other studies, we did not find a relationship between patient demographic characteristics and development of hypocalcemia (15,18-20,27-29), and although several authors have reported a relationship between hyperthyroidism and hypocalemia $(1,7,28)$, our study (like those of Lombardi and cols. (29), Higgins and cols. (18) and Scurry and cols. (15) did not observe this relationship. Additionally, we found no relationship with the number of parathyroid glands identified or transplanted, which is in agreement with other authors $(18,19,30)$.

\section{CONCLUSION}

Serum PTH determinations one hour after total thyroidectomy and the decrease in PTH levels from the preoperative baseline are safe and reliable predictors of symptomatic hypocalcemia. A single measurement one hour after surgery is slightly more accurate and more cost-effective, since only one measurement is required.

Disclosure: no potential conflict of interest relevant to this article was reported.

\section{REFERENCES}

1. Fewins J, Simpson CB, Miller FR. Complications of thyroid and parathyroid surgery. Otolaryngol Clin North Am. 2003;36(1):189-206.

2. Hegner CF. A history of thyroid surgery. Ann Surg. 1932;95(4):481-92.

3. Coffey A, Petti G. Endocrinology. In: Bailey B, Jonhson J, Konut R, editors. Head and Neck Surgery - Otolaryngology. Philadelphia: J. B. Lippincott Co; 1993. p. 135-48.

4. Soon PS, Magarey CJ, Campbell P, Jalaludin B. Serum intact parathyroid hormone as a predictor of hypocalcaemia after total thyroidectomy. ANZ J Surg. 2005;75(11):977-80.

5. Mayo $\mathrm{CH}$, Pemberton JJ. Surgery of the thyroid and its mortality. Ann Surg. 1923;78(2):145-9.

6. Glinoer D, Andry G, Chantrain G, Samil N. Clinical aspects of earIy and late hypocalcaemia afterthyroid surgery. Eur J Surg Oncol. 2000;26(6):571-7.

7. ReeveT,Thompson NW. Complications of thyroid surgery: how to avoid them, how to manage them, and observations on their possible effect on the whole patient. World J Surg. 2000;24(8):971-5.

8. Gonçalves Filho J, Kowalski LP. Posoperative complications of thyroidectomy for differentiated thyroid carcinoma. Am J Otolaryngol. 2004;25(4):225-30.

9. Vescan A, Witterick I, Freeman J. Parathyroid hormone as a predictor of hypocalcaemia after thyroidectomy. Laryngoscope. 2005;115(12):2105-8.

10. Quiros RM, Pesce CE, Wihelm SM, Djuricin G, Prinz RA. Intraoperative parathyroid hormone levels in thyroid surgery are predictive of postoperative hypoparathyroidism and need for vitamin $D$ supplementation. Am J Surg. 2005;189(3):306-9.

11. Chia SH, Weisman RA, Tieu D, Kelly C, Dillmann WH, Orloff LA. Prospective study of perioperative factors predicting hypocalcaemia after thyroid and parathyroid surgery. Arch Otolaryngol Head Neck Surg. 2006;132(1):41-5.
12. Husein M, Hier MP, Al-Abdulhadi K, Black M. Predicting calcium status pos thyroidectomy with early calcium levels. Otolaryngol Head Neck Surg. 2002;127(4):289-93.

13. Bentrem DJ, Rademaker A, Angelos P. Evaluation of serum calcium levels in predicting hypoparathyroidism after total/near-total thyroidectomy or parathyroidectomy. Am Surg. 2001;67(3):251-2.

14. Nahas ZS, FarraqTY, Lin FR, Belin RM, Tufano RP. A safe and cost-effective short hospital stay protocol to identify patients at low risk for the development of significant hypocalcemia after total thyroidectomy. Laryngoscope. 2006;116(6):906-10.

15. Scurry WC, Beus KS, Hollenbeak CS, Stack BC. Perioperative parathyroid hormone assay for diagnosis and management of postthyroidectomy hypocalcaemia. Laryngoscope. 2005;115(8):1362-6.

16. Lindblom P, Westerdahl J, Bergenfelz A. A low parathyroid hormone levels after thyroid surgery: a feasible predictor of hypocalcemia. Surgery. 2002;131(5):515-20.

17. Lam A, Kerr P. Parathyroid hormone: an early predictor of postthyroidectomy hypocalcemia. Laryngoscope. 2003;113(12):2196-200.

18. Higgins KM, Mandell DL, Govindaraj S, Genden EM, Mechanick $\mathrm{JI}$, Bergman DA, et al.The role of intraoperative rapid parathyroid hormone monitoring for predicting thyroidectomy-related hypocalcemia. Arch Otolaryngol Head Neck Surg. 2004;130(1):63-7.

19. Lombardi CP, Raffaelli M, Princi P, Santini S, Boscherini M, De Crea $\mathrm{C}$, et al. Early prediction of post thyroidectomy hypocalcemia by one single iPTH measurement. Surgery. 2004;136(6):1236-41.

20. Pattou F, Combemale F, Fabre S, Carnaille B, Decoulx M, Wemeau $\mathrm{JL}$, et al. Hypocalcemia following thyroid surgery: incidence and prediction of outcome. World J Surg. 1998;22(7):718-24.

21. AES Guidelines G. Australian Endocrine Surgeons Guidelines AES06/01. Postoperative parathyroid hormone measurement and early discharge after total thyroidectomy: analysis of Australian data and management recommendations. ANZ J Surg. 2007;77(4):199-202.

22. Di Fabio F, Casella C, Bugari G, lacobello C, Salerni B. Identification of patients at low risk for thyroidectomy-related hypocalcemia by intraoperative quick PTH. World J Surg. 2006;30(8):1428-33.

23. Ghaheri BA, Liebler SL, Andersen PE, Schuff KG, Samuels MH, Klein RF, et al. Perioperative parathyroid hormone levels in thyroid surgery. Laryngoscope. 2006;116(4):518-21.

24. Grodski S, Farrell S. Early postoperative PTH levels as a predictor of hypocalcaemia and facilitating safe early discharge after total thyroidectomy. Asian J Surg. 2007;30(3):178-82.

25. McLeod IK, Arciero C, Noordzij JP, Stojadinovic A, Peoples G, Melder PC, et al. The use of rapid parathyroid hormone assay in predicting postoperative hypocalcemia after total or completion thyroidectomy. Thyroid. 2006;16(3):259-65.

26. Payne RJ, Tewfik MA, Hier MP,Tamilia M, Mac Namara E, Young J, et al. Benefits resulting from 1-and 6-hour parathyroid hormone and calcium levels after thyroidectomy. Otolaryngol Head Neck Surg. 2005;133(3):386-90.

27. Richards ML, Bingener-Casey J, Pierce D, Strodel WE, Sirinek KR. Intraoperative parathyroid hormone assay: an accurate predictor of symptomatic hypocalcemia following thyroidectomy. Arch Surg. 2003;138(6):632-6.

28. Abboud B. Risk factors for postthyroidectomy hypocalcemia. J Am Coll Surg. 2002;195(4):456-61.

29. Lombardi CP, Raffaelli M, Princi P, Dobrinja C, Carrozza C, Di Stasio $E$, et al. Parathyroid hormone levels 4 hours after surgery do not accurately predict post-thyroidectomy hypocalcemia. Surgery. 2006;140(6):1016-23.

30. Sasson AR, Pingpank JFJ, Wetherington RW, Hanlon AL, Ridge JA. Incidental parathyroidectomy during thyroid surgery does not cause transient symptomatic hypocalcemia. Arch Otolaryngol Head Neck Surg. 2001;127(3):304-8. 